\title{
Investigation of permanent magnet synchronous machine with recuperation block
}

\author{
Andrei Khitrov, Alexander Khitrov \\ Pskov State University, Electro mechanic Faculty. \\ Address: Russian Federation, Pskov, Lenin square, 2
}

\begin{abstract}
PMSM) are getting increasingly involved in electrical engineering and electric power sector. The possible application for PMSM is autonomous decentralized low-power source which requires electric starter-generator.

Structure designing electric starter-generator for the autonomous cogeneration plant based on the rotary-vane external combustion vehicle (RVECE) is mostly consists of designing electric energy generating system. But the designing and investigating system starting operating modes is also of interest.

The paper considers structures of the starter-generator for autonomous low-power sources based on RVECE, the test stand composition and the experiment results.
\end{abstract}

Keywords: permanent magnet synchronous machine, recuperation block, autonomous electrical supply system, starter-generator set, test stand.

\section{INTRODUCION}

Despite their comparatively high cost permanent magnet synchronous machines (motors) (PMSM) are getting increasingly involved in electrical engineering and electric power sector. Because of the top energetic characteristics among modern electromechanical converters PMSM are used both in low-speed highaccuracy motion control systems (brushless DC motors - BLDC) and in very high-speed systems having a primary filed of application covering gas turbine generators, compressor drives, expansion machines and electromechanic energy storages $[1,2]$.

The possible application for PMSM is autonomous decentralized low-power source which requires electric starter-generator. Aspects of structure designing electric starter-generator for the autonomous cogeneration plant based on the rotaryvane external combustion engine (as well as the features and advantages of this type of engines) were considered in [3,4].

Fig. 1 shows the diagram of electrical energy generating using intermediate DC link (power factor corrector (DC/DC) 2) and two bidirectional blocks such as active front end (AFE) converter 1 and inverter 3 along with the corresponding control systems $4,5,6[5]$.

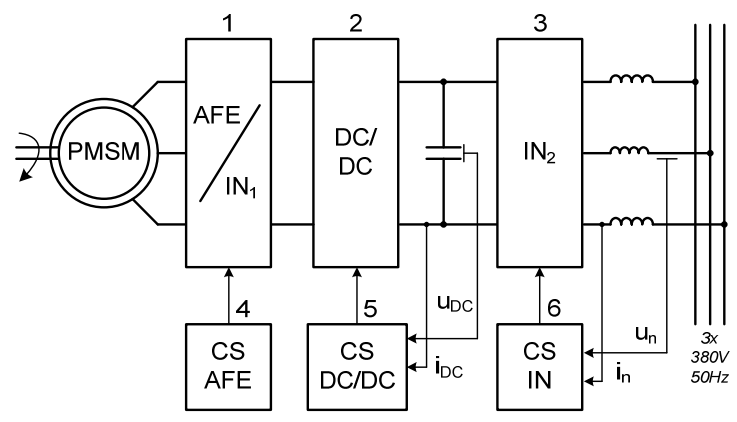

Fig. 1. The diagram of the autonomous generator plant with PMSM.

The referenced paper [3] contains the results of modeling and experiments in generator mode of the plant while investigation of system starting operating modes is also of interest.

\section{PERMANENT-MAGNET SYNCHRONOUS MOTOR SYSTEM STARTING}

It is expected that the start of the plant can be performed both from the network and from accumulator battery (battery start is the only option for autonomous work). The structures of converters applying for starting are shown in fig. 2. DC/DC converter can be switched off in the case of network start or the option of start from $48 \mathrm{~V}$ battery or can be 
used to increase the battery voltage and to feed to he DC link.

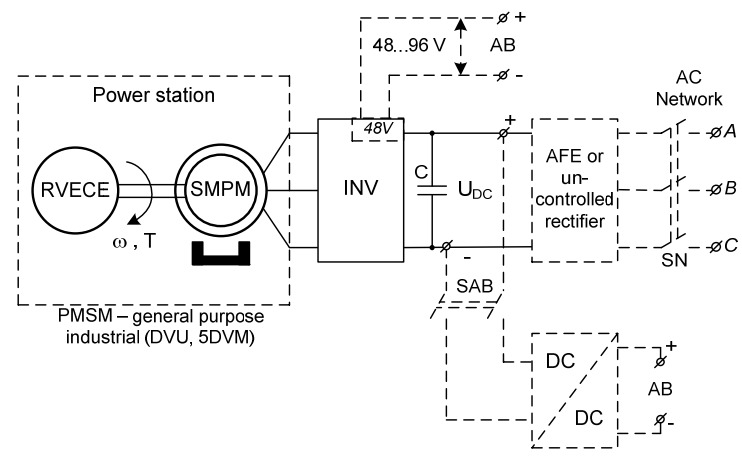

Fig. 2. The structure of the electrical subsystem of the autonomous power supply system based on rotary-vane external combustion engine.

The department of electric drive and automatics of Pskov State University has the test stand for the investigation of PMSM systems [6,7]. It was designed for the experiments with general purpose PMSM both in the motor mode and the generator mode. The test stand is embedded in the learning process for specialization «Electric drive, energy efficiency and autonomous energetics» in the courses «Mobile power supply plants and generating sets» and «Permanent magnet synchronous machines in electrical engineering and electric power sector».

Fig. 3 shows the structure of the test bench. The set connections shown allow to carry out experiments with recuperation block while varying the load for PMSM.

The set includes:

- recuperation block (RB) ЭПВ-Р (OOО «ЧАЭЗЭЛПРИ» Chelyabinsk), two connected to it frequency converters: inverter ACSM (ABB product) having vector control system and direct torque control system (DTC) and inverter Unidrive (Control Techniques product) operating in vector pulse-width modulation mode of the base vectors,

- three electromechanical converters: PMSM of DVU2M type, induction motor of 4A series having two shafts and PMSM of 9C type (ABB product) composing the complete electric drive together with the converter ACSM, equipped with encoder (EN).

Testing mode is selected by circuit breakers FM1FM3. The experiments were performed to research the processes of start, reverse and load step in the PMSM system when powered from a three-phase AC voltage with recuperation block and without it.

Fig. 4 shows plots of starting and load rising when powered from a three-phase network without using recuperation block with the following agreed notations:

1 - curve of speed changing,

2 - curve of current changing,
3 - curve of mechanical torque changing (the torque is measured as a percentage of the rated value), 4 - curve of DC link voltage changing.

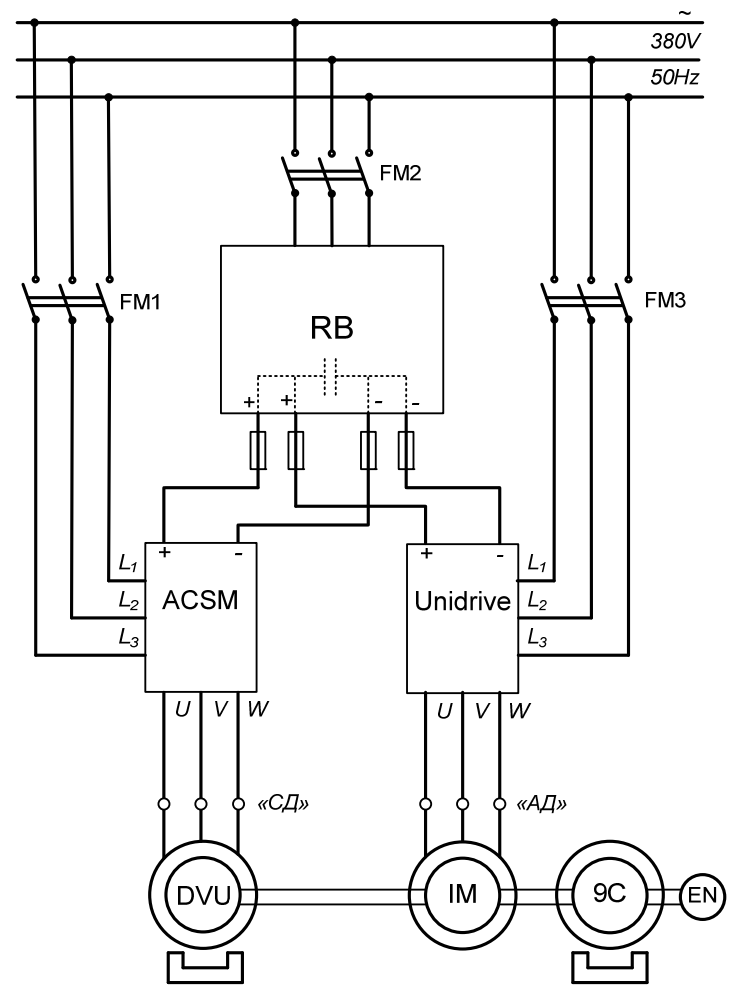

Fig. 3. The test stand structure.
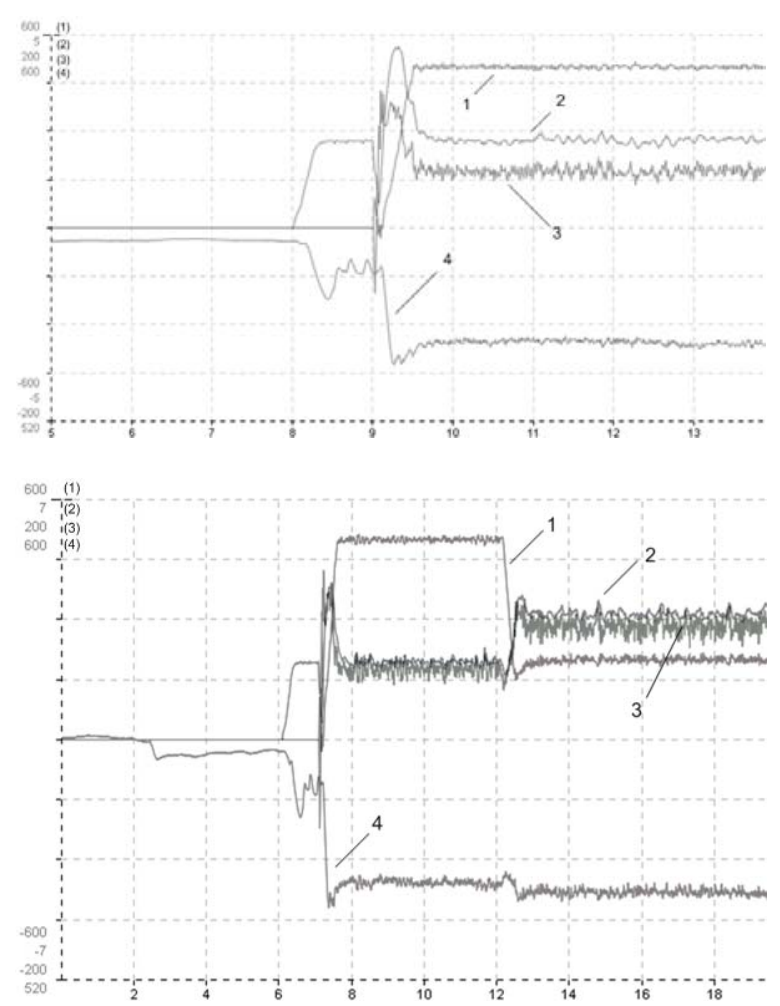

Fig. 4. PMSM modes without RB 
Fig.5 shows plots of starting and load rising when powered from a three-phase network using recuperation block and the same notations as notations for fig.4.

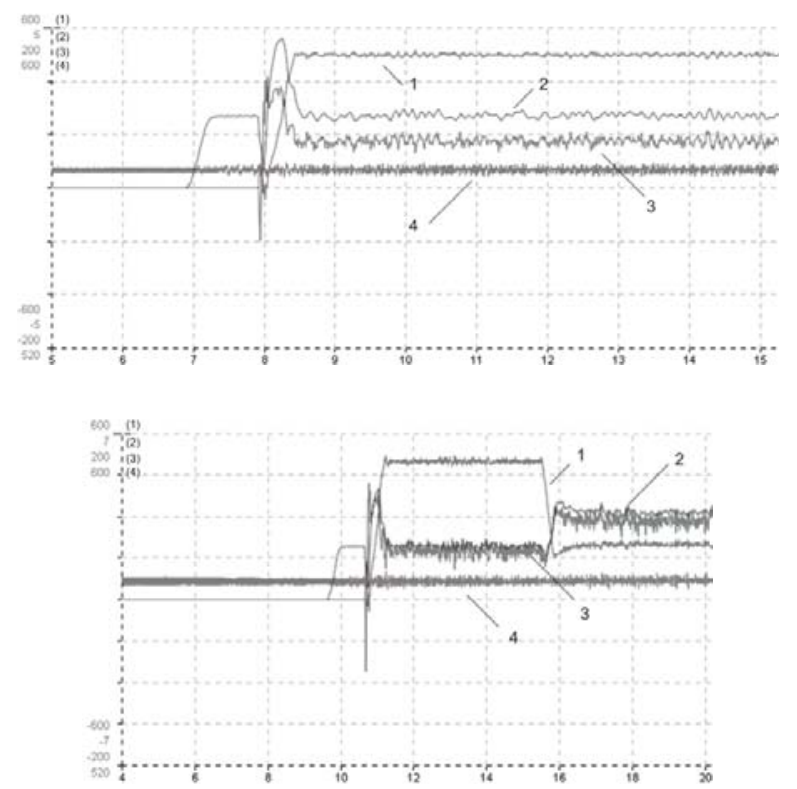

Fig 5. PMSM modes with RB.

The plots shown are obtained by using ABB Drive Studio software.

\section{CONCLUSION}

The results of the investigations allow to draw several conclusions:

- creation of experimental sets (test stands) for permanent magnet synchronous and induction motors modes investigations is recommended to be build using recuperation blocks (AFE converters): that allows to expand dynamic modes research when using visualization tools (software oscilloscope) of modern frequency converters;

- setting recuperation block instead of uncontrolled rectifier on the input of the inverter allows to improve electromagnetic capability (EMC) with a power network and to optimize electromagnetic transients on the DC link at starting and reversing frequencycontrolled electric drives;

- when PMSM is used as the generator for the set with variable-speed engine (occurring in non-constant PMSM shaft speed), the electric energy generation system should be built as shown in the diagram in fig.1;
- researches shown that for creating low-power generating systems $(10-20 \mathrm{~kW})$ based on PMSM in autonomous power sets (cogeneration plants) it is necessary to develop the inverter (DC/AC) having input DC voltage 48-100 V, having built-in semiconductor $\mathrm{DC} / \mathrm{DC}$ «transformer» (power factor corrector) and forming output three-phase $\mathrm{AC}$ voltage of industrial frequency.

\section{REFERENCES}

[1]. Шумов Ю.Н., Сафонов А.С. Сверхскоростные и ультраскоростные синхронные машины с возбуждением от постоянных магнитов (обзор зарубежных публикаций). Электричество №3, 2014.

[2]. Аракелян А.К., Афанасьев А.А. Вентильные электрические машины в системах регулируемых электроприводов: Учебное пособие для вузов: В 2 т. Т.2.М.:Высш.шк.,2006.-518c.

[3]. Khitrov A.I., Khitrov A.A. Electrical subsystem of the low power cogeneration plant with low-speed vehicle. Environment. Technology. Resourses. Proceeding of the 9th International Scientific and Practical Conference, 2013. Volume II. Rezekne. p.119-123.

[4]. Перминов А. Л., Хитров А. А., Хитров А. И. Мехатронная система «магнитоэлектрический синхронный двигатель активный выпрямитель» для автономной системы электроснабжения на базе роторно-лопастной машины с внешним подводом тепла. Труды VII Международной (VIII Всероссийской) конференции по автоматизированному электроприводу АЭП-2012: ФГБОУВПО "Ивановский государственный энергетический университет им. Ленина". - Иваново, 2012. -708 c. c. $330-335$

[5]. Хитров А.И., Хитров А.А. Система управления электрической частью автономной когенерационной установки малой мощности с использованием твердотельных реле. Сборник статей Международной научно-практической конференции. Уфа: РИЦ БашГУ, $2014-244 \mathrm{c}$.

[6]. Хитров А.И., Федотов И.М., Хитров А.А. Экспериментальный стенд для исследования режимов работы асинхронных и вентильных двигателей современных электроприводов. Известия ТулГУ. Технические науки. Выпуск 3. ч.4, 2010. 262 с.

[7]. Федотов И.М., Хитров А.А. Structure designing of test stand for investigation of variable frequency electric drives. Cilvēks. Vide. Tehnologijas: 16 starptautiskās studentu zinātniski praktiskās konferences rakstu krājums 2012. gada 25. aprīlis. Rēzekne: 2012. - 464 lpp. p. 448-452.

[8]. Харитонов С. А. Электромагнитные процессы в системах генерирования электрической энергии для автономных объектов. - Новосибирск: Изд-во НГТУ, 2011. - 536с.

[9]. Мелешин В.И., Овчинников Д.А. Управление транзисторными преобразователями электроэнергии. М. Техносфера, 2011. - $576 \mathrm{c}$.

[10]. Плохов И.В., Донченко М.А., Лукьянов Ю.Н. Энергоэффективная автономная энергоустановка нового поколения. Доклад на международной конференции «Инновационные технологии 2009». М.:Иннотехэкспо, 2009. 